\title{
Influence of disease on iron status
}

\author{
BY MARK WORWOOD
}

Department of Haematology, University of Wales College of Medicine, Heath Park, Cardiff CF4 4XN

\section{DISTRIBUTION OF IRON IN THE BODY}

Most of the $\mathrm{Fe}$ in the body is found in the $\mathrm{O}_{2}$-binding protein, haemoglobin, of the erythrocytes. However, $\mathrm{Fe}$ is also essential for $\mathrm{O}_{2}$ utilization within the cell. Table 1 summarizes the main Fe-containing components within the body.

Fig. 1 illustrates the major pathways of Fe metabolism in man. The most important pathway in terms of Fe turnover is the delivery of Fe to the erythroid marrow for the synthesis of haemoglobin and the breakdown of erythrocytes at the end of their lifespan with Fe returning to the plasma. Fe excretion is limited to about $1 \mathrm{mg} / \mathrm{d}$ in men but menstruation increases total Fe losses to about $2 \mathrm{mg} / \mathrm{d}$ in women.

\section{IMPORTANT COMPONENTS OF IRON METABOLISM}

\section{Plasma iron transport}

The Fe-binding protein of the plasma is transferrin (for review, see De Jong et al. 1990). Transferrin is very similar to lactoferrin found in granulocytes and in milk. Both are monomeric glycoproteins with a molecular mass of about $80 \mathrm{kDa}$. Transferrin binds two atoms of $\mathrm{Fe}^{3+}$ and each $\mathrm{Fe}$-binding site requires both $\mathrm{Fe}$ and an anion which is usually carbonate or bicarbonate. Transferrin has a very high affinity for Fe. Fe can be released by lowering the $\mathrm{pH}$ to less than 5.5 but there are specific mechanisms for delivering Fe to cells (see later).

The plasma concentration of transferrin in adults is normally about $2.5 \mathrm{~g} / \mathrm{l}$ and transferrin can bind $1.4 \mu \mathrm{g} \mathrm{Fe} / \mathrm{mg}$. The protein is normally $20-40 \%$ saturated with $\mathrm{Fe}$.

\section{Delivery of iron to cells}

Delivery of transferrin-Fe to cells (particularly to immature erythrocytes for haemoglobin synthesis) takes place by interaction with specific receptors in the cell membrane (Huebers \& Finch, 1987) followed by receptor-mediated endocytosis, removal of Fe and release of apotransferrin from the cell. The transferrin receptor is a transmembrane glycoprotein consisting of two identical subunits of molecular mass $95 \mathrm{kDa}$ joined by a disulfide bond (Trowbridge \& Schackelford, 1986).

\section{Haem synthesis}

Quantitatively, the major pathway of Fe metabolism involves haem synthesis and breakdown and this haem is largely present in haemoglobin. Haem synthesis and its control in the erythroid cell and the liver have been reviewed by Bottomley \& Muller-Eberhard (1988). 
Table 1. Distribution of iron in the body (70 $\mathrm{kg}$ man)

\begin{tabular}{llr}
\hline \hline Protein & Location & Fe content (mg) \\
\hline Haemoglobin & Erythrocytes & 3000 \\
Myoglobin & Muscle & 400 \\
Cytochromes, other haem and Fe, S proteins & All tissues & 50 \\
Transferrin & Plasma and extravascular fluid & 5 \\
Ferritin and haemosiderin & Liver, spleen and bone marrow & $0-1000$ \\
\hline
\end{tabular}

\section{Haem catabolism}

This is an enzymic process mediated by the enzyme haem oxygenase which is located in the endoplasmic reticulum. The enzyme requires NADPH and molecular oxygen (Schacter, 1988). Enzyme activity (in the rat) is highest in the spleen and then in the bone marrow, liver, brain, kidney and lung. There is also activity in the intestinal mucosa. The immediate fate of the Fe released from haem is unknown but Fe is rapidly returned to the plasma as well as being incorporated into ferritin in the cells breaking down haem.

\section{Iron storage proteins}

Fe is stored in cells as ferritin which is a soluble, spherical protein enclosing a core of Fe. Particularly high concentrations are present in the liver, spleen and bone marrow. Ferritin is also found in low concentrations in plasma (Worwood, 1990). Human apoferritin (i.e. the molecule devoid of $\mathrm{Fe}$ ) has a molecular mass of $480 \mathrm{kDa}$ and is composed of twenty-four subunits of molecular mass about $19 \mathrm{kDa}$. The subunits form a nearly spherical shell that encloses a central core containing up to 4500 atoms of $\mathrm{Fe}$ in the form of ferric hydroxyphosphate.

Human ferritins are made up of two types of subunit in varying proportions. In liver and spleen, the $L$ subunit dominates. In the most acidic isoferritins found in the heart and in erythrocytes, the $\mathrm{H}$ subunit predominates. The various isoferritins appear to have different functions. In Fe-loaded tissues it is the L-rich isoferritins which predominate, although $\mathrm{H}$ rich isoferritins have the highest rates of $\mathrm{Fe}$ uptake in vitro.

Haemosiderin is a degraded form of ferritin in which the protein shells have partly disintegrated allowing the $\mathrm{Fe}$ cores to aggregate (Richter, 1984). It is usually found in lysosomes and may be seen under the light microscope after tissue sections have been stained with potassium ferrocyanide in the presence of $\mathrm{HCl}$ (Prussian blue or Perl's reaction).

\section{Regulation of synthesis of transport and storage proteins}

Studies in animals and cultured cells show that apoferritin is synthesized in response to $\mathrm{Fe}$ administration. This mechanism is well understood and is exercised at the level of translation (Klausner et al. 1993). The $5^{\prime}$ untranslated region of the ferritin mRNA contains a sequence which forms a 'stem loop'. This has been termed an Fe response element. Cytoplasmic proteins which bind to this sequence and prevent translation have been identified. In the presence of $\mathrm{Fe}$ this repressor protein (Fe-regulatory protein; IRP) is unable 
Absorption and excretion

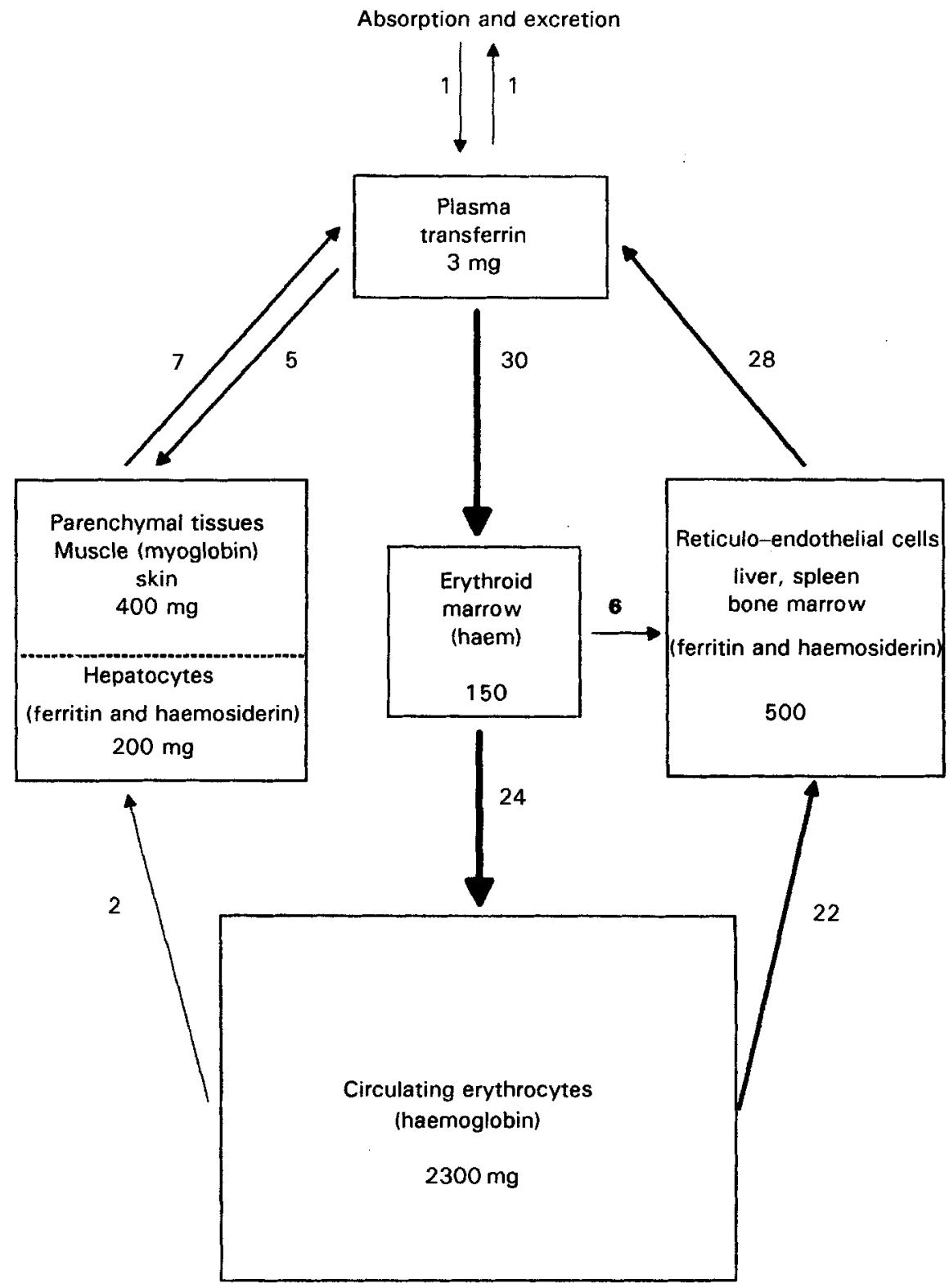

Fig. 1. The major pathways of iron metabolism. Values shown are $\mathrm{mg} \mathrm{Fe} / \mathrm{d}$. The Fe in muscle is largely haem and in hepatic parenchymal cells ferritin and haemosiderin. (From British Nutrition Foundation, 1995; with permission.)

to bind the mRNA, polysomes form and translation proceeds. The IRP is soluble aconitase (EC 4.2.1.3) and in its Fe-replete state it may function as aconitase. A related mechanism operates in reverse for the transferrin receptor. There are 'stem loop' sequences in the $3^{\prime}$ untranslated region and protein binding prevents degradation of mRNA, hence $\mathrm{Fe}$ deficiency enhances transferrin-receptor synthesis. This translational regulation also applies to erythroid 5-aminolevulinate synthase (EC 2.3.1.37) and aconitase. 


\section{Regulation of iron absorption}

The body Fe content is normally maintained at a constant level by variation in the amount of Fe absorbed. It is clear that this depends on the availability of Fe in the diet and is also influenced both by the storage $\mathrm{Fe}$ content of the body and by the rate of erythropoiesis. However, the way in which $\mathrm{Fe}$ absorption is regulated in the intestinal epithelial cell remains largely a mystery (Peters et al. 1988).

\section{IRON STATUS}

Normal Fe status implies both the presence of erythropoiesis which is not limited by Fe and a small reserve of 'storage $\mathrm{Fe}$ ' to cope with normal physiological functions and to permit a rapid response to acute loss of blood (Fe). The limits of normality are difficult to define and some argue that physiological normality is an absence of storage Fe (Sullivan, 1992). However, the extremes of Fe-deficiency anaemia and haemochromatosis are well understood. There is also the possibility of maldistribution of Fe within the body. In the anaemia associated with inflammation or infection, where there is a partial failure of erythropoiesis and of Fe release from phagocytic cells in liver, spleen and bone marrow, there is an accumulation of $\mathrm{Fe}$ as ferritin and haemosiderin in these cells. Thus, determination of $\mathrm{Fe}$ status requires an estimate of the amount of haemoglobin-Fe in the body (usually by measuring the haemoglobin concentration of the blood) and the level of storage Fe. Occasionally further investigations into Fe loss, Fe absorption and flow-rates within the body are also required. Fig. 2 illustrates the situation for normal Fe status, Fe deficiency, Fe overload and the anaemia of chronic disease. Fig. 3 shows the various indicators of $\mathrm{Fe}$ status which are in clinical use.

\section{Tissue iron concentrations (iron stores)}

The liver and bone marrow are important and relatively accessible storage sites and the amount of Fe present can be estimated either visually using the Prussian blue reaction on tissue sections or by a chemical determination. Methods for chemical and histological assessment of tissue Fe concentrations have been described by Torrance \& Bothwell (1980). Chemical determination of liver Fe concentration is most widely applied for the demonstration of Fe overload and allows the important distinction to be made between the relatively minor increases in liver non-haem-Fe sometimes found in patients with cirrhosis of the liver and Fe overload associated with inherited haemochromatosis (Bassett et al. 1986). Estimation of Fe concentration in the bone marrow is, in contrast, usually carried out by the histochemical method and is used to detect the absence of storage Fe. In particular, assessing marrow Fe histologically distinguishes between true Fe deficiency and other chronic disorders in which there is impaired release of Fe from reticulo-endothelial cells.

Serum ferritin concentrations. Small amounts of ferritin circulate within the plasma. Serum ferritin concentrations are normally within the range $15-300 \mu \mathrm{g} / \mathrm{l}$; values are lower in children than in adults and from puberty to middle age mean concentrations are higher in men than in women (Worwood, 1982). A concentration of less than approximately $15 \mu \mathrm{g} / 1$ is usually found in the absence of storage Fe. Ferritin concentrations are determined by sensitive immunological assays, usually ELISA. 


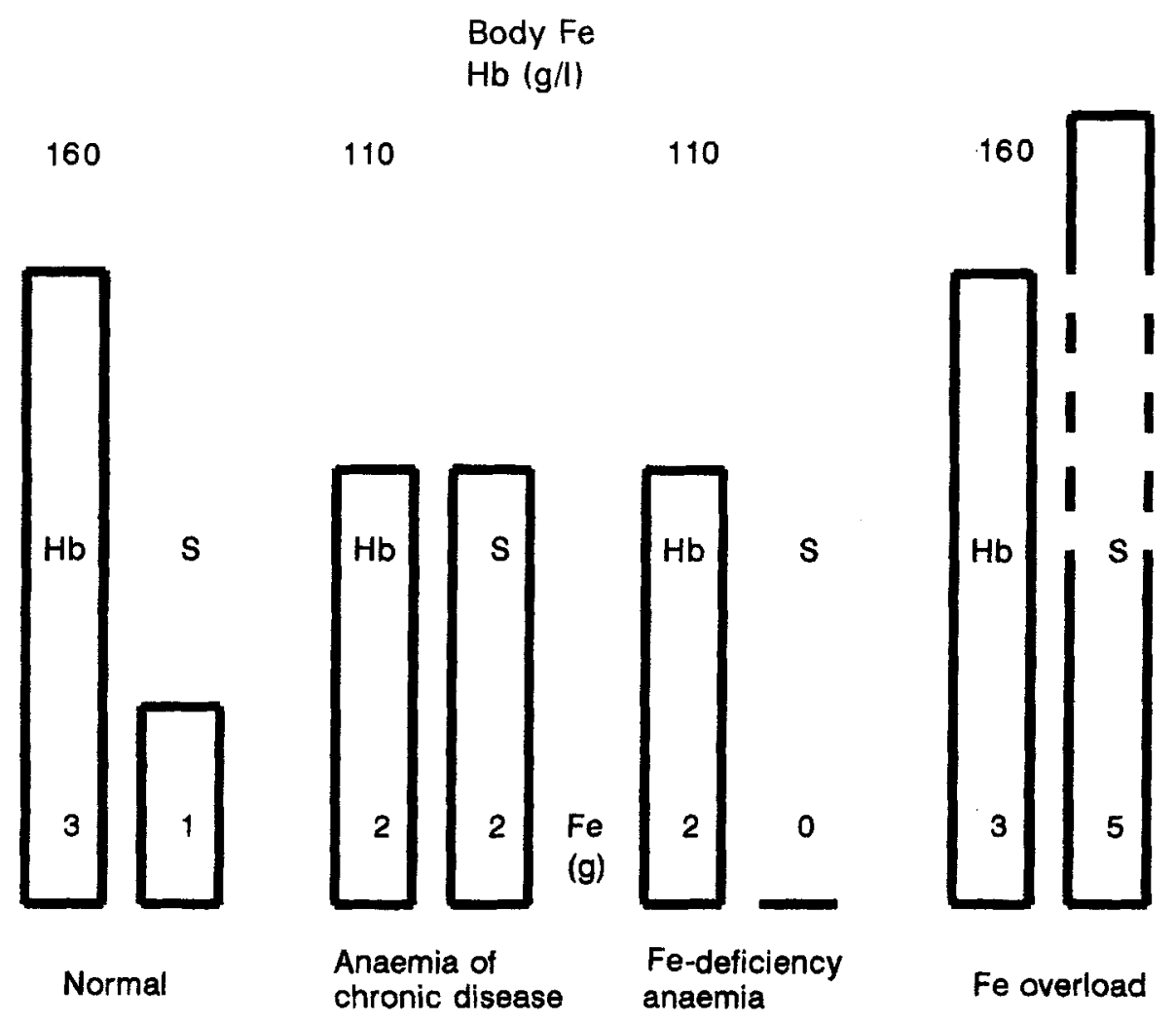

Fig. 2. Body iron: total haemoglobin $(\mathrm{Hb})$ and storage $\mathrm{Fe}(\mathrm{S})$ levels in various physiological conditions. Total haemoglobin and storage Fe levels $(\mathrm{g})$ are shown. The normal subject is a $70 \mathrm{~kg}$ man.

\section{Transport iron}

Serum Fe concentrations can be measured by colorimetric methods (International Committee for Standardization in Haematology, 1990) which are relatively specific for transferrin Fe and do not measure haem-Fe. Measurement of serum Fe concentrations alone provides little useful clinical information because of the considerable variation from hourto-hour and day-to-day in normal individuals (see p. 415). More information can be obtained by measuring both the serum Fe concentration and the total Fe-binding capacity (TIBC) from which the percentage of transferrin saturation with $\mathrm{Fe}$ may be calculated. The TIBC is a measurement of transferrin concentration and may be estimated by saturating the transferrin Fe-binding capacity with excess $\mathrm{Fe}$ and removing the excess by adding soluble $\mathrm{MgCO}_{3}$ or some other absorbent. This is followed by determination of the Fe content of the saturated serum. As an alternative transferrin concentrations may be measured directly by immunological assay. Normally, in adults, the median Fe concentration is about $17 \mu \mathrm{mol} / \mathrm{l}$, the TIBC is approximately $65 \mathrm{~mol} \mathrm{Fe} / \mathrm{l}$ and the transferrin saturation approximately $25 \%$. A transferrin saturation of $16 \%$ or less is usually considered to indicate an inadequate $\mathrm{Fe}$ supply for erythropoiesis (Bainton \& Finch, 1964). A raised TIBC (greater than $70 \mu \mathrm{mol} / \mathrm{l}$ ) is characteristic of a deficiency of storage Fe. 


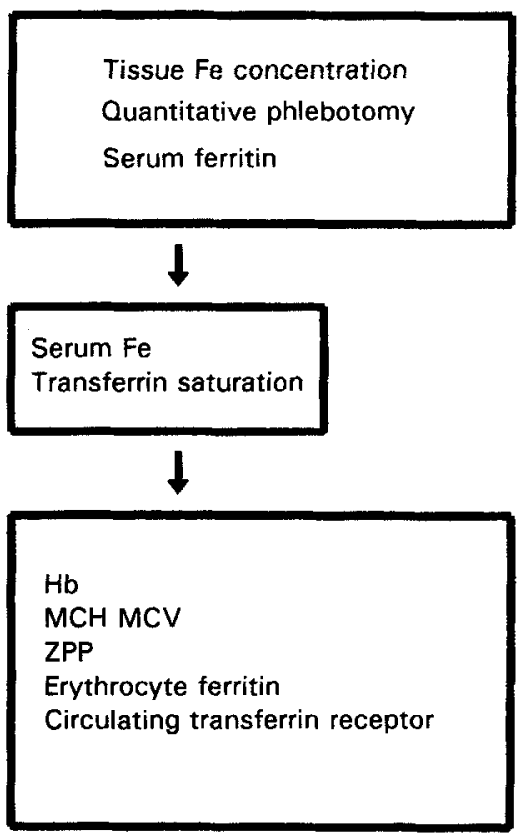

Fig. 3. Indicators of iron status, relating to stores $\rightarrow$ transport $\rightarrow$ erythropoiesis. $\mathrm{Hb}$, haemoglobin; $\mathrm{MCH}$, mean cell haemoglobin; MCV, mean cell volume, ZPP, zinc protoporphyrin.

\section{Functional iron status (detection of iron-deficient erythropoiesis)}

The primary measurement here is the determination of haemoglobin concentration (Dacie \& Lewis, 1995). Fe deficiency is indicated by a low mean cell volume (MCV) and a low mean cell haemoglobin concentration $(\mathrm{MCH})$. Thus, blood cell analysers can indicate the presence of microcytic anaemia which can be due to a reduced supply of Fe to the bone marrow or to a deficit in haemoglobin synthesis such as in thalassaemia. Further tests are usually necessary to distinguish between simple Fe deficiency (absence of storage $\mathrm{Fe}$ ) and a supply deficiency that is secondary to another disease process (see p. 416).

Erythrocyte protoporphyrin (zinc protoporphyrin). This assay has been performed for many years as a test for $\mathrm{Pb}$ poisoning. More recently, there has been much interest in its use in evaluating the Fe supply to the bone marrow. The 'free' protoporphyrin concentration of erythrocytes increases in $\mathrm{Fe}$ deficiency. A widely-used technique directly measures the fluorescence of zinc protoporphyrin ( $\mu \mathrm{mol} / \mathrm{mol} \mathrm{haem}$ ) in a haematofluorometer (Labbe \& Rettmer, 1989). The normal range in adults is less than $80 \mu \mathrm{mol} / \mathrm{mol}$ haem.

Serum transferrin receptor. Another indicator of Fe-deficient erythropoiesis is the serum transferrin receptor level. Soluble transferrin receptors are detectable in the circulation by immunoassay and appear to reflect the number of transferrin receptors on immature erythrocytes and, thus, the level of bone marrow erythropoiesis (Cazzola \& Beguin, 1992). A mean level of $5.6 \mathrm{mg} / \mathrm{l}$ has been reported by Flowers et al. (1989). The assay is potentially of considerable value as it provides an alternative to the very cumbersome ferrokinetic studies which were previously necessary. In normal subjects the serum transferrin receptor level also provides a sensitive indicator of functional $\mathrm{Fe}$ 
deficiency in subjects without Fe stores who have not yet developed Fe-deficiency anaemia (Skikne et al. 1990).

\section{METHODOLOGICAL AND BIOLOGICAL VARIATION OF ASSAYS}

The blood assays vary greatly in both methodological and biological stability (British Nutrition Foundation, 1995). Haemoglobin concentrations are stable and a simple and well-standardized method of determination (Dacie \& Lewis, 1995) ensures relatively low day-to-day variation in individuals. Automated cell counters analyse at least 10000 cells and, thus, reduce errors. The more complicated procedures involved in immunoassays mean higher methodological variation for ferritin assays and overall $\mathrm{CV}$ of approximately $15 \%$. The serum Fe determination is an example of extremes with reasonably low methodological variation coupled with extreme physiological variability giving an overall 'within subject' CV of approximately $30 \%$ when venous samples are taken at the same time of the day.

\section{IRON STATUS AND DISEASE}

\section{Iron deficiency}

Table 2 shows the changes that take place for the various blood measurements for assessing Fe status in Fe-deficiency anaemia. There is little difficulty in making such a diagnosis. Fedeficiency anaemia has been estimated to affect 500 million people worldwide. It is considered that Fe deficiency even in the absence of anaemia has serious consequences in terms of both mental and physical development and in work performance (Cook et al. 1994).

Recently there has been some interest in what has been called 'functional $\mathrm{Fe}$ deficiency'. This situation arises in the treatment of patients undergoing renal dialysis with erythropoietin in order to cure their anaemia. Sometimes a failure to respond is due to the fact that although there is apparently sufficient storage $\mathrm{Fe}$ available, this Fe cannot be mobilized rapidly enough to regenerate haemoglobin (Macdougal et al. 1989). A more rapid response is assured by injecting Fe. Functional Fe deficiency can be detected by the presence of a raised percentage of hypochromic erythrocytes (greater than $8 \%$ ).

\section{Iron overload}

Genetic haemochromatosis is one of the most common inherited conditions in Northern European populations (Worwood, 1994). The prevalence varies from 1 in 2000 to 1 in 200 . A prevalence of 1 in 400 means that approximately $10 \%$ of the population may carry one copy of the gene. Diagnosis of haemochromatosis and $\mathrm{Fe}$ overload requires the demonstration of an elevated transferrin saturation (greater than $60 \%$ in men, $50 \%$ in women) and a raised serum ferritin concentration (greater than $300 \mu \mathrm{g} / \mathrm{l}$ in men and $200 \mu \mathrm{g} /$ 1 in women). Both transferrin saturation and ferritin concentration must be abnormal in a second sample and the diagnosis usually requires demonstration of Fe overload by measurement of the liver Fe concentration. Early detection allows successful treatment by phlebotomy and the identification of other family members at risk from Fe overload. Once cirrhosis of the liver has developed, this cannot be reversed and in many cases hepatoma develops. The recent identification of a candidate, causative mutation for haemochroma- 
Table 2. Cut-off points for defining iron status in adults

(From British Nutrition Foundation, 1995; with permission)

\begin{tabular}{|c|c|c|c|c|c|}
\hline Factor & Overload & Normal & $\begin{array}{l}\text { Fe-depleted } \\
\text { non-anaemic }\end{array}$ & $\begin{array}{l}\text { Fe-deficient } \\
\text { erythropoiesis }\end{array}$ & Anaemia \\
\hline Haemoglobin $(\mathrm{g} / \mathrm{l})$ & - & $\begin{array}{l}\geq 130^{*} \\
\geq 120 \dagger\end{array}$ & $\begin{array}{l}\geq 130^{*} \\
\geq 120^{+}\end{array}$ & $\begin{array}{l}\geq 130^{*} \\
\geq 120^{\dagger}\end{array}$ & $\begin{array}{l}<130^{*} \\
<120^{\dagger}\end{array}$ \\
\hline Ferritin $(\mu \mathrm{g} / \mathrm{l})$ & $\begin{array}{l}>300^{*} \\
>200 \dagger\end{array}$ & $\geq 13$ & $<13$ & $<13$ & $<13$ \\
\hline Transferrin saturation (\%) & $\begin{array}{l}>60^{*} \\
>50 \dagger\end{array}$ & $>16$ & $>16$ & $<16$ & $<16$ \\
\hline Zinc protoporphyrin ( $\mu \mathrm{mol} / \mathrm{mol}$ haem) & - & $<80$ & $<80$ & $\geq 80$ & $\geq 80$ \\
\hline Serum transferrin receptor $(\mathrm{mg} / \mathrm{l})$ & - & $<8.5$ & $<8 \cdot 5$ & $\geq 8.5$ & $\geq 8.5$ \\
\hline
\end{tabular}

*Values for men.

$\dagger$ Values for women.

tosis in a novel MHC class I-like gene (Feder et al. 1996) provides the opportunity to develop effective genetic testing.

\section{Anaemia associated with inflammation, infection and other chronic disorders}

Inflammation, infection, surgery or malignancy are often associated with anaemia. As well as anaemia, there may be a low serum Fe concentration and evidence of increased levels of storage $\mathrm{Fe}$ in the bone marrow. It is now thought that inflammation etc. leads to the release of interleukin $1 \beta(\mathrm{IL} 1 \beta)$ and other cytokines. IL1 $\beta$ stimulates ferritin synthesis (Rogers, 1996) and also inhibits erythropoiesis. The initial effect seems to be the stimulus of apoferritin synthesis which traps Fe in phagocytic cells. This leads to a reduced supply of $\mathrm{Fe}$ to the bone marrow. Distinguishing between patients with the anaemia of chronic disease who have no storage $\mathrm{Fe}$ and those who have apparently adequate amounts of storage $\mathrm{Fe}$ has been a problem for many years. Many clinical studies have demonstrated that patients with the anaemia of chronic disease, with no stainable Fe in the bone marrow, may have serum ferritin concentrations considerably in excess of $15 \mu \mathrm{g} / 1$ and there has been much debate (Witte, 1991) about the practical application of the serum ferritin assay in this situation. Values of less than $15 \mu \mathrm{g} / \mathrm{l}$ indicate the absence of storage Fe and values of greater than $100 \mu \mathrm{g} / \mathrm{l}$ indicate the presence of storage Fe. It is the 'grey' area from 15 to 100 $\mu \mathrm{g} / \mathrm{l}$ which is difficult to interpret. Although it would seem logical to combine the assay of serum ferritin with a measure of disease severity such as the erythrocyte sedimentation rate or $\mathrm{C}$ reactive protein, this approach does not appear to be significantly better than measuring serum ferritin concentration on its own (Coenen et al. 1991). Ferguson et al. (1992) have suggested that in patients with chronic disease, only those with an absence of storage Fe have raised levels of the serum transferrin receptor. However, later studies have not suggested that the assay of serum transferrin receptor adds much information to the assay of serum ferritin (see Kurer et al. 1995). Various algorithms involving measurement of serum ferritin concentration, transferrin saturation, $\mathrm{MCV}$ and $\mathrm{MCH}$ have been proposed. In general these appear to offer some improvement on a simple determination of serum ferritin concentration (see Mulherin et al. 1996).

\section{Liver disease}

Serum ferritin concentrations are particularly influenced by the presence of liver disease. Extremely high concentrations may be found in patients with hepatitis and cirrhosis of the 
liver (Prieto et al. 1973). In the context of liver disease, the only simple interpretation is that a serum ferritin concentration in the normal range excludes Fe overload. In hospital practice, apparently unexplained elevations of serum ferritin concentration are found in patients with liver disease, in patients with human immunodeficiency virus infection and patients with malignant disorders (Lee \& Means, 1995). The highest concentrations of serum ferritin are found in patients with transfusional Fe overload as well as liver disease.

\section{Other factors affecting measurements of iron status}

Starvation, or even fasting briefly, can cause elevation of the serum ferritin concentration (Lundberg et al. 1984) and vitamin C deficiency may reduce both ferritin and $\mathrm{Fe}$ concentrations (Chapman et al. 1982). This is perhaps the only known instance where serum ferritin concentrations may be depressed in the absence of tissue Fe deficiency. Haemolysis can increase serum ferritin concentrations and serum Fe concentrations. Very high concentrations of circulating ferritin and $\mathrm{Fe}$ are found in patients with active erythrophagocytosis (Esumi et al. 1988). One interesting cause of apparently unexplained ferritinaemia is that associated with inherited cataract formation. It has now been demonstrated that there is a mutation in the 'stem loop' structure of the ferritin L subunit which causes the very high concentrations of ferritin found in this condition apparently in the absence of high levels of storage Fe (Beaumont et al. 1995).

\section{What is normal iron status?}

There has been much interest in recent years in the proposition that even moderate increases in storage Fe may be associated with pathology, for example, in higher rates of myocardial infarction (Salonen et al. 1992). In general, it is difficult to demonstrate that elevations in serum ferritin concentration actually reflect enhanced levels of storage $\mathrm{Fe}$ rather than being a result of the chronic disease process described previously.

\section{CONCLUSION}

Most diagnostic problems in $\mathrm{Fe}$ metabolism can be resolved by a careful consideration of haemoglobin-Fe concentration, erythrocyte indices and serum ferritin concentration. However, serum ferritin concentration must be assessed in terms of other disease processes particularly infection, inflammation and liver disease. The determination of serum Fe and transferrin saturation is essential in the diagnosis of genetic haemochromatosis and this includes the screening of other family members. Although both zinc protoporphyrin and measurements of circulating transferrin receptor have particular value in epidemiological studies, they probably add relatively little to the diagnostic armoury at present.

\section{REFERENCES}

Bainton, D. F. \& Finch, C. A. (1964). The diagnosis of iron deficiency anaemia. American Journal of Medicine 37, 62-70.

Bassett, M. L., Halliday, J. W. \& Powell, L. W. (1986). Value of hepatic iron measurements in early haemochromatosis and determination of critical iron concentration associated with fibrosis. Hepatology 6, 24-29.

Beaumont, C., Leneuve, P., Devaux, I., Scoazec, J. Y., Berthier, M., Loiseau, M. N., Grandchamp, B. \& Bonneau, D. (1995). Mutation in the iron responsive element of the $L$ ferritin mRNA in a family with dominant hyperferritanaemia and cataract. Nature Genetics 11, 444-447. 
Bottomley, S. S. \& Muller-Eberhard, U. (1988). Pathophysiology of heme synthesis. Seminars in Hematology 25, 282-302.

British Nutrition Foundation (1995). Iron - Nutritional and Physiological Significance. The Report of the British Nutrition Foundation's Task Force. London: Chapman and Hall.

Cazzola, M. \& Beguin, Y. (1992). New tools for clinical evaluation of erython function in man (Annotation). British Journal of Haematology 80, 278-284.

Chapman, R. W. G., Hussain, M. A. M., Gorman, A., Laulicht, M., Politis, D., Flynn, D. M., Sherlock, S. \& Hoffbrand, A. V. (1982). Effect of ascorbic acid deficiency on serum ferritin concentration in patients with $\beta$ thalassaemia major and iron overload. Journal of Clinical Pathology 35, 487-491.

Coenen, J. L. L. M., van Dieijen-Visser, M. P., van Pelt, J., van Deursen, C. T. B. M., Fickers, M. M. F., Wersch, J. W. J. \& Brombacher, P. J. (1991). Measurements of serum ferritin used to predict concentrations of iron in bone marrow in anaemia of chronic disease. Clinical Chemistry 37, 560-563.

Cook, J. D., Skikne, B. S. \& Bynes, R. D. (1994). Iron deficiency: The global perspective. Advances in Experimental Medicine and Biology 356, 219-228.

Dacie, J. V. \& Lewis, S. M. (1995). Practical Haematology. Edinburgh: Churchill Livingstone.

de Jong, G., van Dijk, J. P. \& van Eijk, H. G. (1990). The biology of transferrin. Clinica Chimica Acta 190, $1-46$.

Esumi, N., Ikushima, S., Hibi, S., Todo, S. \& Imashutuku, S. (1988). High serum ferritin level as a marker of malignant histocytosis and virus associated hemophagocytic syndrome. Cancer 61, 2071-2076.

Feder, J. N., Gnirke, A., Thomas, W., Tsuchihashi, Z., Ruddy, D. A., Basava, A., Dormishian, F., Domingo, R. Jr, Ellis, M. C., Fullan, A., Hinton, L. M., Jones, N. L., Kimmel, B. E., Kronmal, G. S., Lauer, P., Lee, V. K., Loeb, D. B., Mapa, F. A., McClelland, E., Meyer, N. C., Mintier, G. A., Moeller, N., Moore, T., Morikang, E., Prass, C. E., Quintana, L., Starnes, S. M., Schatzman, R. C., Brunke, K. J., Drayna, D. T., Risch, N. J., Bacon, B. R. \& Wolff, R. K. (1996). A novel MHC class I-like gene is mutated in patients with hereditary haemochromatosis. Nature Genetics 13, 399-408.

Ferguson, B. J., Skikne, B. S., Simpson, K. M., Baynes, R. D \& Cook, J. D. (1992). Serum transferrin receptor distinguishes the anemia of chronic disease from iron deficiency anaemia. Joumal of Laboratory and Clinical Medicine 119, 385-390.

Flowers, C. H., Skikne, B. S., Covell, A. M. \& Cook, J. D. (1989). The clinical measurement of serum transferrin receptor. Journal of Laboratory and Clinical Medicine 114, 368.

Huebers, H. A. \& Finch, C. A. (1987). The physiology of transferrin and transferrin receptors. Physiological Reviews 67, 520-582.

International Committee for Standardization in Haematology (1990). Revised recommendations for the measurements of the serum iron in human blood. British Journal of Haematology 75, 615-616.

Klausner, R. D., Rouault, T. A. \& Harford, J. B. (1993). Regulating the fate of mRNA: the controls of cellular iron metabolism. Cell 72, 19-28.

Kurer, S. B., Seifert, B., Miche1, B., Ruegg, R. \& Fehr, J. (1995). Prediction of iron deficiency in chronic inflammatory rheumatic disease anaemia. British Journal of Haematology 91, 820-826.

Labbe, R. F. \& Rettmer, R. L. (1989). Zinc protoporphyrin: a product of iron deficient erythropoiesis. Seminars in Hematology 26, 40-46.

Lee, M. H. \& Means, R. T. Jr (1995). Extremely elevated serum ferritin levels in a university hospital: associated diseases and clinical significance. American Journal of Medicine 98, 566-571.

Lundberg, P. A., Lindstedt, G., Anderson, T., Branegârd, B., Lundquister, G. \& Nyström, E. (1984). Increase in serum ferritin concentration induced by fasting. Clinical Chemistry 30, 161-163.

MacDougal, I. C., Hutton, R. D., Cavill, I., Coles, G. A. \& Williams, J. D. (1989). Poor response to treatment of renal anaemia with erythropoiesis corrected with iron given intravenously. British Medical Journal 299, 157158.

Mulherin, D., Skelly, M., Saunders, A., McCarthy, D., O'Donoghue, D., Fitzgerald, D., Bresnihan, B. \& Mulcahy, H. (1996). The diagnosis of iron deficiency in patients with rheumatoid arthritis and anaemia: an algorithm using simple laboratory measures. Journal of Rheumatology 23, 237-240.

Peters, T. J., Raja, K. B., Simpson, R. J. \& Snape, S. (1988). Mechanisms and regulation of iron absorption. Annals of the New York Academy of Sciences 526, 141-147.

Prieto, J., Barry, M. \& Sherlock, S. (1973). Serum ferritin in patients with iron overload and with acute and chronic liver diseases. Gastroenterology 68, 525-533.

Richter, G. W. (1984). Studies of iron overload. Rat liver siderosome ferritin. Laboratory Investigation 50, 2635.

Rogers, J. T. (1996). Ferritin translation by interleukin 1 and interleukin 6: the role of sequences upstream of the start codons of the heavy and light subunit genes. Blood 87, 2525-2537.

Salonen, J. T., Nyyssönen, K., Korpela, H., Tuomilehto, J., Seppänen, R. \& Salonen, R. (1992). High stored iron levels are associated with excess risk of myocardial infarction in eastern Finnish men. Circulation 86, 803811 .

Schachter, B. A. (1988). Heme catabolism by heme oxygenase: physiology, regulation and mechanism of action. Seminars in Hematology 25, 349-369. 
Skikne, B. S., Flowers, C. H. \& Cook, J. D. (1990). Serum transferrin receptor: a quantitative measure of tissue iron deficiency. Blood 75, 1870-1876.

Sullivan, J. L. (1992). Stored iron as a risk factor for ischemic heart disease. In Iron and Human Disease, pp. 295-312 [R. B. Lauffer, editor]. Boca Raton, Florida: CRC Press.

Torrance, J. D. \& Bothwell, T. H. (1980). Tissue iron stores. In Iron. Methods in Hematology, vol. 1, pp. 90-115 [J. D. Cook, editor]. New York: Churchill Livingstone.

Trowbridge, I. S. \& Schackelford, D. A. (1986). Structure and function of transferrin receptors and their relationship to cell growth. Biochemical Society Symposia 51, 117-129.

Witte, D. L. (1991). Can serum ferritin be effectively interpreted in the presence of the acute-phase response? Clinical Chemistry 37, 484-485.

Worwood, M. (1982). Ferritin in human tissues and serum. Clinics in Haematology 11, $275-307$.

Worwood, M. (1990). Ferritin. Blood Reviews 4, 259-269.

Worwood, M. (1994). Genetics of haemochromatosis. Bailliere's Clinical Haematology 7, 903-918. 